\title{
Comparison of Biomass and C Storage in Three Promising Fast Growing Tree Plantations under Agroforestry System in Sub-humid Tropics of Chhattisgarh, India
}

\author{
SL Swamy*, Alka Mishra \\ Guru Ghasidas Vishwavidyalaya (A Central University), Bilaspur, Chhattisgarh, India 495009 \\ *Corresponding Author: swamy_101@yahoo.com
}

Copyright $(2014$ Horizon Research Publishing All rights reserved.

\begin{abstract}
The anthropogenic activities are alarmingly increasing the concentrations of $\mathrm{CO}_{2}$ in the atmosphere leading to the climate change. Agriculture ecosystem especially tropical agriculture is most vulnerable to climate change posing a serious threat on food, nutritional security and livelihoods of poor farming communities. Agroforestry technologies indeed offer viable opportunity to mitigating the atmospheric accumulation of $\mathrm{CO}_{2}$ and other Greenhouse gases, and potential for transforming to resilient farming systems and further help smallholder farmers of many tropical countries like India for adapting to climate change. However, the magnitude of $\mathrm{C}$ sequestration in many agroforestry systems is still unknown, which primarily depends on the choice of tree species and managerial practices. The present study corresponds to a part of the long term project on Gmelina arborea, Populus deltoides and Ceiba pentandra based agroforestry systems evaluated for $\mathrm{C}$ storage potentials in sub-humid tropics Chhattisgarh, India. At 5 years age, total biomass varied from $12.9 \mathrm{Mg} \mathrm{ha}^{-1}$ to $25.1 \mathrm{Mg} \mathrm{ha}^{-1}$ in C. pentandra, while $9.9 \mathrm{Mg} \mathrm{ha}^{-1}$ to $21.4 \mathrm{Mg}$ $\mathrm{ha}^{-1}$ in $G$. arborea. The biomass was greater under narrow tree spacing. A significant growth and biomass variation was also exhibited by $P$. deltoides clones, where the total biomass ranged from $48.5 \mathrm{Mg} \mathrm{ha}^{-1}$ to $62.2 \mathrm{Mg} \mathrm{ha}^{-1}$. At 5 years age, total C storage in $G$. arborea stands ranged from 4.3 to 9.4 $\mathrm{Mg} \mathrm{ha}^{-1}, P$. deltoides from 22.5 to $30.1 \mathrm{Mg} \mathrm{ha}^{-1}$ and $C$. pentandra from 4.5 to $10.1 \mathrm{Mg} \mathrm{ha}^{-1}$. Soil organic C significantly enhanced under agroforestry system. Soil organic $\mathrm{C}$ in $G$. arborea stands increased from $6.8 \%$ to $11.9 \%, P$. deltoides from $12.7 \%$ to $20.6 \%$, and C. pentandra from $5.5 \%$ to $14.5 \%$ under different treatments. $P$. deltoides showed the greater potential for $\mathrm{C}$ sequestration than $G$. arborea and $C$. pentandra under agroforestry system. Clones $65 / 27$ and D121 of $P$. deltoides were found outstanding and suggested to adopt under agroforestry. Soybean and wheat yields were decreased under agroforestry systems, which advocate introducing appropriate tree management practices to improve the complementarity to exploit synergies between tree and crop components. The paper discusses the
\end{abstract}

management implications and strategies for sustainable tree-crop production and improving $\mathrm{C}$ sequestration under agroforestry systems for mitigating the climate change.

Keywords Adaptation, Biomass, Carbon Sequestration, Climate Change, Greenhouse Gases, Mitigation, Tree-crop Interaction, Yield Losses

\section{Introduction}

Fifth Assessment Report of Intergovernmental Panel on Climate Change (IPCC) emphasized to develop a strong rationale for mitigation and adaptation to climate change especially in developing countries of tropics to face the challenge of climate change (IPCC, 2014).There is growing concern among scientific community to evolve resilient agro-ecosystem to climate change as the livelihoods and economy of majority of population in tropics are dependent on climate sensitive agriculture sector (Verchot et al., 2007; Murthy et al., 2013; Nair and Nair, 2014). The small and marginal farmers are more vulnerable and facing the brunt of climate change in India. As more than $90 \%$ of the population in rural areas belongs to this community and agriculture is the mainstay of their livelihood and economy (Nath and Behera, 2011).

Impact of climate change on agriculture is striking in many parts of India including the state of Chhattisgarh, which is located in the eastern part of the country popularly known as rice-bowl of eastern India (Murthy et al., 2013). Anthropogenic activities like deforestation, industrialization and rapid land use transformation are destructing the environment and contributing for the change in regional climate (Puri and Nair, 2004). According to a report of Sastri (2010), the rainfall decreased by $5-35 \%$ and number of rainy days decreased from 75 to 50 days in different regions of Chhattisgarh. The maximum temperature reached to peak beyond $46{ }^{\circ} \mathrm{C}$ during summer (May). In some pockets, the 
climate changed from moist sub-humid type to semi-arid and other pockets from moist sub-humid to dry sub-humid. The negative impacts of climate change on agriculture are clearly evident in the region (Sastri, 2010). The large farmers have initiated mitigation and adaptation activities by changing the land management and agronomic practices as part of their climate smart agriculture. However, small and marginal farmers could not able to shift from traditional agriculture due to lack of knowledge and poor socio-economic conditions. Under these circumstances, the agroforestry systems which could help agro-ecosystem to adapt to greater climate variability as well as mitigate greenhouse gases through $\mathrm{C}$ sequestration and by buffering crops from the effects of temperature and precipitation variation (Verchot $e t$ al., 2007; Chauhan et al., 2012; Nair and Nair, 2014). Numerous reports are available on $\mathrm{C}$ sequestration potential of agroforestry systems (Albrecht and Kandji, 2003; Chauhan et al., 2011; Nair and Nair, 2014). Fast growing tree plantations are considered highly efficient carbon sinks because of their adaptability and relatively high rates of productivity (Kumar and Nair, 2012).

However, the potentials of many multipurpose trees on C sequestration and crop productivity are yet to be exploited under agroforestry systems in Chhattisgarh, India. Gmelina arborea, Populus deltoides and Ceiba pentandra are three promising fast growing multipurpose species grown by farming communities (Puri and Nair, 2004). G. arborea is an indigenous tree practiced by the farmers for its timber and pulp wood, whereas the $P$. deltoides for match sticks and packaging boxes. The wood of $C$. pentandra on the other hand is an excellent source of match splint and packing cases, besides the silk cotton from pods mainly used for stuffing pillows, mattresses, life-belts etc. All three species have good economic value and readily sold in local markets. Despite the diverse value and economic benefits, only a limited scientific work was done (Puri et al., 2002; Swamy et al., 2003) and studies are lacking on comparative evaluation of species under agroforestry system. Therefore, a long term study was initiated with a goal to compare the biomass, tree-crop interaction, nutrient cycling and $\mathrm{C}$ sequestration potentials under $G$. arborea, $P$. deltoides and $C$. pentandra based agroforestry system in sub-humid tropics of Chhattisgarh, India. The present study is a part of this project related to the comparison of biomass and $\mathrm{C}$ storage as an indicator of $\mathrm{C}$ sequestration potential. The results of five year studies provide useful insights and opportunity to exploit the potentials of species under agroforestry system for C sequestration on degraded agricultural sites.

\section{Material and Methods}

\subsection{Study Site}

The study was conducted at Forestry Research Farm of Indira Gandhi Agricultural University, Raipur (latitude $21^{\circ}$ $12^{\prime} \mathrm{N}$ and longitude $81^{\circ} 36^{\prime} \mathrm{E}$ ), Chhattisgarh, India. The climate of the region is sub-humid tropical with an annual precipitation of $1200-1400 \mathrm{~mm}$, of which $80 \%$ is received during July to October. Mean monthly maximum and minimum temperatures range from $27{ }^{\circ} \mathrm{C}$ and $13{ }^{\circ} \mathrm{C}$ in December to $42{ }^{\circ} \mathrm{C}$ and $28{ }^{\circ} \mathrm{C}$ in May, respectively. The topography is almost plain with $<1 \%$ slope. The soil type is Vertisol, relatively fertile with black deep clayey soil characterized by fine texture, sticky in nature and angular blocky structure with good water holding capacity. It is fairly rich in organic carbon $(0.43 \pm 0.04 \%)$, available potassium $\left(358.6 \pm 28.5 \mathrm{~kg} \mathrm{ha}^{-1}\right)$ and medium in available nitrogen $(253$ $\left.\pm 11.5 \mathrm{~kg} \mathrm{ha}^{-1}\right)$ and low in available phosphorous $(10.8 \pm 0.95$ $\mathrm{kg} \mathrm{ha}^{-1}$ ) with a $\mathrm{pH}$ of $7.5 \pm 0.2$ (Puri et al., 2002). The site was an abandoned agricultural land, which was fallow and not cultivated for the last five years.

\subsection{Site Preparation and Establishment of Agroforestry Experiments}

Three agroforestry experiments of $G$. arborea, $C$. pentandra and $P$. deltoides were simultaneously established on abandoned agricultural land in study site. Each experiment was conducted on 1.2 ha of land leaving $15 \mathrm{~m}$ buffer to serve as control (treeless plots) for growing sole crop without any trees. The care has also taken to raise the guard rows of trees on boundaries to avoid the inter-specific competition. The methods adopted for establishing plantations and growing crops under trees in the form of agroforestry system are as follows.

\subsubsection{Establishment of G. arborea and C. pentandra Stands}

The land was ploughed and levelled for the establishment of $G$. arborea and C. pentandra based agroforestry systems. Nursery raised three-month-old uniform size (height $0.78 \pm$ $0.15 \mathrm{~m}$; collar diameter $0.65 \pm 0.1 \mathrm{~cm}$ ) healthy seedlings of $G$. arborea and $C$. pentandra were transplanted in $45 \mathrm{~cm}^{3}$ pits at three spacing ( $4 \times 4 \mathrm{~m}, 4 \times 6 \mathrm{~m}$ and $4 \times 8 \mathrm{~m}$ ) following three replications. A sum total of 432 trees were maintained for each species comprising 192 trees in $4 \times 4 \mathrm{~m}, 144$ trees in $4 \mathrm{x}$ $6 \mathrm{~m}$ and 96 trees in $4 \times 8 \mathrm{~m}$ spacing. Sixteen (16) trees falling in the central rows were marked for taking observations on trees and inter crops. A basal dose of $100 \mathrm{~kg} \mathrm{ha}^{-1} \mathrm{~N}, 40 \mathrm{~kg}$ $\mathrm{ha}^{-1} \mathrm{P}$ and $80 \mathrm{~kg} \mathrm{ha}^{-1} \mathrm{~K}$ was applied at the time of planting. After first year, nitrogen@120 kg ha ${ }^{-1}$, phosphorous@40 $\mathrm{kg} \mathrm{ha}^{-1}$ and potassium @ $80 \mathrm{~kg} \mathrm{ha}^{-1}$ were applied every year for two years. $\mathrm{N}$ was applied in two equal splits (July and March) while $\mathrm{P}$ and $\mathrm{K}$ as a single dose in July. The plots were irrigated weekly in summer (March-June) and at monthly interval in winter (October to February), while no irrigation was provided in rainy season (July-September). The total water given ranged from 600 to $800 \mathrm{~mm}$ per annum. Pruning of lower branches was carried every year up to $1 / 3^{\text {rd }}$ of crown height of trees at the beginning of winter (November). The crops were grown under different tree spacing of 5 yr-old stands of G. arborea and C. pentandra.

\subsubsection{Establishment of $P$. deltoides Clones}


In another experiment, clonal trial of Poplar was established as an agroforestry system. For this experiment, initially 106 clones of Populus deltoides (Poplar) were collected from different parts of north India and were evaluated in nursery and field conditions for three years. Among 106 clones, 19 clones were found promising and among them five best clones viz. 65/27, G3, G48, D121 and S7C1 were selected for establishing agroforestry system. These clones were chosen on the basis of their growth rate, crown characteristics and adaptability in juvenile stages. The 1-year-old entire-transplants (ETP) were planted at 4 × $5 \mathrm{~m}$ spacing as monoclonal blocks in a randomized block design. Each clone was replicated three times with a total number of 36 trees maintained for a clone per replication (plot) and thus in all forming 540 trees in the trail ( 5 clones $\mathrm{x} 3$ replications $\mathrm{x}$ 36 trees per replication). Sixteen trees (16) located centrally rows were marked for recording observations on trees and intercrops. Each tree was fertilised with $50 \mathrm{~g}$ of single super phosphate (SSP) and $25 \mathrm{~g}$ of muriate of potash. Nitrogen in the form of diammonium phosphate (DAP) was given at 100 $\mathrm{g} \mathrm{plant}^{-1}$ in two split doses (last week of June and September). The fertilization was done initially during the first two years. Plantation was irrigated at weekly in summer (March-June) and fortnightly in winter seasons (October-February). No irrigations were provided during rainy season (July-September). A sum total of 1404 trees were planted for three species which include 432 trees each for $G$. arborea and $C$. pentandra and 540 for five clones of $P$. deltoides.

\subsection{Intercropping of Soybean and Wheat}

Soybean and wheat are the most common crops grown in rainy and winter seasons in study area of Chhattisgarh. Therefore, soybean (Glycine max var. JS 80-21) was intercropped during rainy season (June-November), while wheat (Triticum aesitivum var. GW-273) in winter (November-March) under the stands of $G$. arborea, $C$. pentandra and $P$. deltoides as agroforestry system. The crop treatments were also arranged in a randomized block design and replicated three times. The crop treatments were consistent with tree spacing and clonal treatments. Monospecific crop plots (treeless controls) were established block-wise in the contiguous area for comparative purposes. Crops were grown following local recommendations in respect of agronomical practices and fertiliser applications. The methods followed for measurement of tree growth, biomass, $\mathrm{C}$ storage and yield attributes of crops are described below.

\subsection{Tree Growth and Leaf Area Index (LAI)}

Growth parameters like diameter at breast height (DBH), total height and clean bole were measured in 5 year old stands. Stand density was also recorded by counting the live and dead trees. Diameter at breast height was measured at $1.37 \mathrm{~m}$ on trunk and total tree height by calibrated pole. LAI of trees and amount of PAR (Photosynthetically active radiation ) intercepted by tree canopies were measured using a Plant Canopy Analyser (LAI 2000, LI-COR, Lincoln, NE). A single measurement of LAI was accomplished by taking the LAI 2000 unit outside the experimental plot (in the open) to record an "above canopy reading" of sky brightness and then sampling 10 random locations in the central region of each tree (beneath canopy readings). Care was taken to ensure that the unit was facing the same direction both outside and inside the stand. A sunlit canopy was avoided by taking measurements just after the sunrise and just before sunset when the solar elevation is low. A view restrictor $90^{\circ}$ was used in all measurements to prevent direct sunlight from reaching the sensor and at the same time to occlude the measuring person from the area of view.

\subsection{Stand Biomass}

Biomass estimation of stands was made by harvesting five trees proportionally distributed over the range of stem diameters $(3.5-25 \mathrm{~cm})$ for each species and clones, was selected for destructive sampling. The trees were carefully cut at $15 \mathrm{~cm}$ from ground level. Each tree was further subdivided into components viz., stems, branches and foliage. Fresh weight of these components was determined in the field. The component parts were later sub-sampled for moisture determination and chemical analysis. For quantifying coarse root ( $>5 \mathrm{~mm}$ ) biomass, roots of 25 trees were excavated by the skeleton method (dry excavation) up to $1 \mathrm{~m}^{3}$ soil volume and the fresh weight of roots were measured. All the sub-samples were oven dried at $70^{\circ} \mathrm{C}$ to a constant weight. The total oven-dry weight of each component was calculated by applying oven-dry: fresh weight ratios. Total tree biomass was computed by summing the biomass of stem, branch, foliage and root components. The mean values of the five trees were used for estimating stand biomass. The stand biomass per hectare was calculated from the mean of dry weight totals of plots and expanded to a hectare basis.

\subsection{Analysis in Plant and Soil Samples}

The randomly collected plant samples of foliage, bole, branches and roots of three species were analysed for total $\mathrm{C}$. It was estimated following dry combustion method using Shimadzu TOC - 5000 A with solid sample analysis module. $\mathrm{C}$ quantities in tree components were obtained from the product of total biomass of each component and the average $\mathrm{C}$ concentrations in that component. Total $\mathrm{C}$ storage was achieved by summing the $\mathrm{C}$ quantities in stem, branch, foliage and root components. The carbon quantities were further extrapolated to hectare basis by multiplying with the standing biomass per hectare.

The changes in $\mathrm{C}$ in soils were assessed in agroforestry system after 5 years. Soil samples were randomly collected under three stands (three randomly chosen points in each plot) at $0-20 \mathrm{~cm}$ and $20-40 \mathrm{~cm}$ depths. Soil was analysed for total organic $\mathrm{C}$ following dry combustion method using Shimadzu 
TOC -5000 A with solid sample module. The amount of soil organic $\mathrm{C}$ was determined by multiplying soil weight per given soil volume with mean $\mathrm{C}$ concentration values. The total $\mathrm{C}$ storage in stands (trees) was computed by summing the $\mathrm{C}$ stored in foliage, stem, branch and roots. The total C storage in the system was estimated by adding the $\mathrm{C}$ accumulated in vegetation and soil compartments in a five year period.

\subsection{Statistical Analysis}

Data on growth, biomass, C storage in tree and soil under three stands were analysed following analysis of variance procedures (Steel and Torrie, 1980). The crop yields were also analysed using similar procedure. Significant differences between treatment means for growth, biomass, $\mathrm{C}$ storage and crop yields were tested at $\mathrm{p} \leq 0.05$ using least significant difference (LSD) test.

\section{Results}

\subsection{Growth of G. arborea and $C$. pentandra Stands}

The stand characteristics of G. arborea and C. pentandra are presented in Table 1. Tree stocking varied according to the degree of mortality suffered by each stand. The percent of mortality in stands increased with an increase in tree spacing. The stocking density was higher in C. pentandra, which ranged from $91 \%$ to $95 \%$, while it was comparatively low and varied from $82 \%$ to $91 \%$ in G arborea. A significant variation was found in growth traits of $C$. pentandra due to different tree spacing (Table 1), whereas no such marked differences were observed in G. arborea. Dbh (diameter at breast height) and total tree height were relatively higher in C. pentandra compared to G. arborea. It was observed that Dbh was almost double in stands of $C$. pentandra in comparison to G. arborea. The stands in narrow tree spacing $(4 \times 4 \mathrm{~m})$ recorded slightly better growth than those in the wide spacing $(4 \times 8 \mathrm{~m})$. LAI (leaf area index) was almost similar in both stands and it gradually decreased with an increase in tree spacing, whereas photosynthetically active radiation (PAR) showed reverse trend. PAR levels were increased by $10 \%$ inC . pentadra stands at wide tree spacing(Table 1)

\subsection{Biomass and C Storage in G. arborea and $C$. pentandra Stands}

Biomass showed significant variations in tree components of $G$. arborea and $C$. pentadra stands due to different spacing (Table 2). The higher biomass was found in stands with more stocking density. Among different components, stem contributed a maximum to total tree biomass followed by roots and branches. About $62 \%$ to $65 \%$ to total biomass was augmented by stem component alone in G. arborea, while $56 \%$ to $62 \%$ in $C$. pentandra stands. Foliage contributed from $4.1 \%$ to $4.7 \%$ in G. arborea and $7.3 \%$ to $7.7 \%$ in $C$. pentandra stands. Total biomass was relatively higher in in stands of $C$. pentandra than $G$. arborea. It varied from $12.9 \mathrm{Mg} \mathrm{ha}^{-1}$ to $25.1 \mathrm{Mg} \mathrm{ha}^{-1}$ in C. pentandra and 9.9 $\mathrm{Mg} \mathrm{ha}^{-1}$ to $21.4 \mathrm{Mg} \mathrm{ha}^{-1}$ in G. arborea (Table 2).

Table 1. Stand characteristics of G. arborea and C. pentandra in Agroforestry system

\begin{tabular}{|c|c|c|c|c|c|c|c|c|c|c|}
\hline \multirow{2}{*}{ Spacing (m) } & \multicolumn{2}{|c|}{$\begin{array}{c}\text { Stand density } \\
(\text { trees ha }\end{array}$} & \multicolumn{2}{c|}{ DBH $(\mathrm{cm})$} & \multicolumn{2}{c|}{ Tree height $(\mathrm{m})$} & \multicolumn{3}{|c|}{ LAI } & \multicolumn{2}{|c|}{ PAR $\left(\mu \mathrm{mol} \mathrm{s}^{-1} \mathrm{~m}^{-2}\right)$} \\
\cline { 2 - 12 } & AFS1 & AFS2 & AFS1 & AFS2 & AFS1 & AFS2 & AFS1 & AFS2 & AFS1 & AFS2 \\
\hline $\mathrm{S}_{1}$ & 564 & 596 & 10.1 & 19.7 & 6.58 & 9.29 & 3.45 & 3.36 & 1128.1 & 1023.25 \\
\hline $\mathrm{S}_{2}$ & 364 & 394 & 10.43 & 17.3 & 6.86 & 8.96 & 3.09 & 2.94 & 1184.6 & 1121.57 \\
\hline $\mathrm{S}_{3}$ & 258 & 284 & 10.29 & 17.1 & 7.25 & 8.76 & 2.81 & 2.67 & 1239.6 & 1187.44 \\
\hline $\begin{array}{c}\mathrm{LSD} \\
(\mathrm{P} \leq 0.05)\end{array}$ & 67.8 & 71.2 & $\mathrm{NS}$ & 0.91 & $\mathrm{NS}$ & 0.46 & $\mathrm{NS}$ & 0.31 & $\mathrm{NS}$ & 88.3 \\
\hline
\end{tabular}

Note: AFS1- G. arborea based Agroforestry system; AFS2- C. pentandra based Agroforestry system, $\mathrm{S}_{1}=4 \times 4 \mathrm{~m}, \mathrm{~S}_{2}=4 \times 6 \mathrm{~m}$, $\mathrm{S}_{3}=4 \times 8 \mathrm{~m}, \mathrm{DBH}=$ Diameter at breast height, $\mathrm{LAI}=$ Leaf area index, PAR $=$ Photosynthetically active radiation, NS $=$ Non significant

Table 2. Biomass $\left(\mathrm{Mg} \mathrm{ha}^{-1}\right)$ distribution in tree components of G. arborea and C. pentandra stands in agroforestry system

\begin{tabular}{|c|c|c|c|c|c|c|c|c|c|c|}
\hline \multirow{2}{*}{ Spacing $(\mathrm{m})$} & \multicolumn{2}{|c|}{ Foliage $\left(\mathrm{Mg} \mathrm{ha}^{-1}\right)$} & \multicolumn{2}{|c|}{$\begin{array}{c}\text { Stem } \\
\left(\mathrm{Mg} \mathrm{ha}^{-1}\right)\end{array}$} & \multicolumn{2}{|c|}{$\begin{array}{l}\text { Branches } \\
\left(\mathrm{Mg} \mathrm{ha}^{-1}\right)\end{array}$} & \multicolumn{2}{|c|}{$\begin{array}{c}\text { Roots } \\
\left(\mathrm{Mg} \mathrm{ha}^{-1}\right)\end{array}$} & \multicolumn{2}{|c|}{$\begin{array}{l}\text { Total biomass } \\
\left(\mathrm{Mg} \mathrm{ha}^{-1}\right)\end{array}$} \\
\hline & AFS1 & AFS2 & AFS1 & AFS2 & AFS1 & AFS2 & AFS1 & AFS2 & AFS1 & AFS2 \\
\hline $\mathrm{S}_{1}$ & 0.88 & 1.82 & 13.9 & 13.92 & 2.19 & 3.12 & 4.4 & 6.4 & 21.4 & 25.1 \\
\hline $\mathrm{S}_{2}$ & 0.65 & 1.26 & 9.11 & 10.03 & 1.57 & 2.04 & 3.12 & 3.12 & 14.5 & 16.45 \\
\hline $\mathrm{S}_{3}$ & 0.47 & 0.98 & 6.1 & 8.02 & 1.12 & 1.44 & 2.25 & 2.44 & 9.9 & 12.88 \\
\hline $\begin{array}{c}\text { LSD } \\
(\mathrm{P} \leq 0.05)\end{array}$ & 0.15 & 0.24 & 1.57 & 0.86 & 0.5 & 0.31 & 0.52 & 0.31 & 2.7 & 1.68 \\
\hline
\end{tabular}

Note: AFS1- G. arborea based Agroforestry system; AFS2- C. pentandra based Agroforestry system, $\mathrm{S}_{1}=4 \times 4 \mathrm{~m}, \mathrm{~S}_{2}=4 \times 6 \mathrm{~m}$, $\mathrm{S}_{3}=4 \times 8 \mathrm{~m}, \mathrm{DBH}=$ Diameter at breast height,, $\mathrm{LAI}=$ Leaf area index, $\mathrm{PAR}=$ Photosynthetically active radiation; NS = Non significant 
Carbon concentrations varied among tree components of C. pentandra and G. arborea stands (Fig. 1 and Fig. 2). It was higher in woody components (stem, branches and roots) as compared to non woody components like foliage and twigs. Relatively $\mathrm{C}$ concentrations were higher in components of $G$. arborea compared to the $C$. pentandra. C stocks in G. arborea and C. pentandra showed significant differences (Table 3 ). In 5 year-old stands, the total $C$ storage varied from $4.5 \mathrm{Mg} \mathrm{ha}^{-1}$ to $10.1 \mathrm{Mg} \mathrm{ha}^{-1}$ in C. pentandra, while $4.3 \mathrm{Mg} \mathrm{ha}^{-1}$ to $9.3 \mathrm{Mg} \mathrm{ha}^{-1}$ in G. arborea (Table 2). The contribution by different components for $\mathrm{C}$ storage was in the order: stems $>$ roots $>$ branches $>$ foliage. Slightly a higher C storage was found in stands of $C$. pentandra than $G$. arborea. The $\mathrm{C}$ storage varied according to stocking density, which was higher in narrow tree spacing $(4 \times 4 \mathrm{~m})$ and decreased with an increase in spacing. $C$ sequestration in $C$. pentandra stands ranged from 0.9 to $2 \mathrm{Mg} \mathrm{ha}^{-1} \mathrm{yr}^{-1}$, whereas in G. arborea stands from 0.86 to $1.87 \mathrm{Mg} \mathrm{ha}^{-1} \mathrm{yr}^{-1}$ (Table 3)

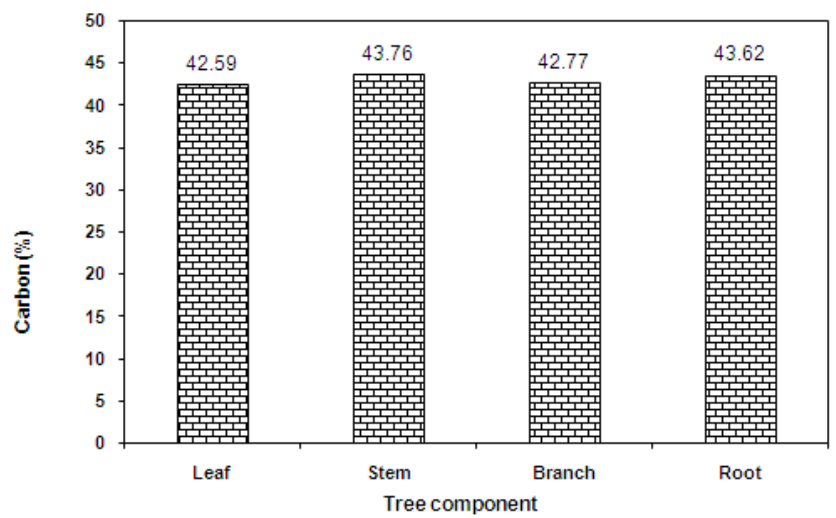

Figure1. Carbon concentration in different components of Gmelina arborea

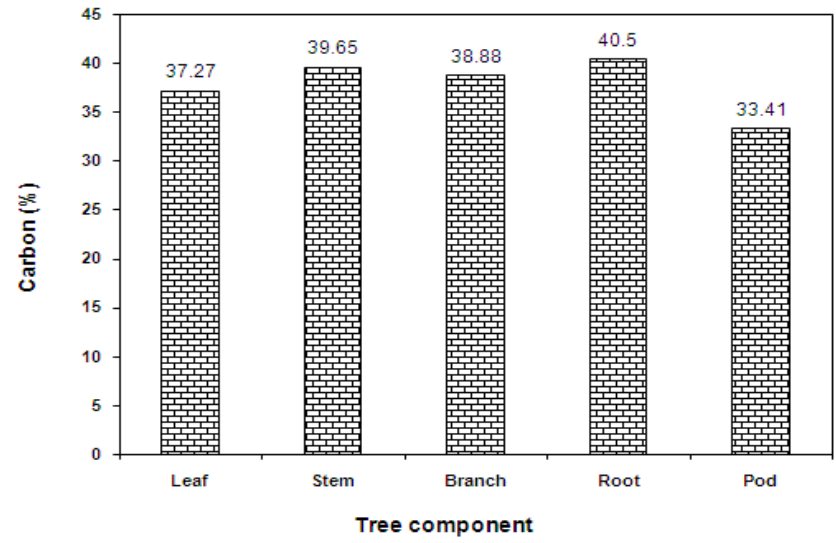

Figure 2. Carbon concentration in different components of Ceiba pentandra.

\subsection{Yields of Soybean and WheaT UNder G. arborea and C. pentandra Based Agroforestry System}

The yields of soybean and wheat exhibited significant variation under stands of $C$. pentandra and $G$. arborea in agroforestry system (Table 4). Yield of crops decreased under agroforestry compared to sole crop system, and also it was more under narrow tree spacing (4 x $4 \mathrm{~m})$. Reduction of yield was comparatively lower in wheat than in soybean. Relatively more yield losses were noticed in C. pentandra in comparison to $G$. arborea based agroforestry system. The yield of soybean decreased from $8.1 \%$ to $34.5 \%$ and wheat from $8.8 \%$ to $13.6 \%$ under different spacing of G. arborea. Similarly, soybean yield decreased from $26.1 \%$ to $43 \%$ and wheat from $5.3 \%$ to $17.8 \%$ under different spacing of $C$. pentandra (Table 4)

Table 3. Carbon stocks $\left(\mathrm{Mg} \mathrm{ha}^{-1}\right)$ in tree components of G. arborea and C. pentandra stands

\begin{tabular}{|c|c|c|c|c|c|c|c|c|c|c|}
\hline \multirow{2}{*}{ Spacing $(\mathrm{m})$} & $\begin{array}{c}\text { Foliage, fruits and pods } \\
\left(\mathrm{Mg} \mathrm{ha}^{-1}\right)\end{array}$ & \multicolumn{2}{|c|}{$\begin{array}{c}\text { Stem } \\
\left(\mathrm{Mg} \mathrm{ha}^{-1}\right)\end{array}$} & \multicolumn{2}{c|}{$\begin{array}{c}\text { Branches } \\
\left(\mathrm{Mg} \mathrm{ha}^{-1}\right)\end{array}$} & \multicolumn{2}{|c|}{$\begin{array}{c}\text { Roots } \\
\left(\mathrm{Mg} \mathrm{ha}^{-1}\right)\end{array}$} & \multicolumn{2}{c|}{$\begin{array}{c}\text { Total C stock } \\
\left.(\mathrm{Mg} \mathrm{ha})^{-1}\right)\end{array}$} \\
\cline { 2 - 13 } & AFS1 & AFS2 & AFS1 & AFS2 & AFS1 & AFS2 & AFS1 & AFS2 & AFS1 & AFS2 \\
\hline $\mathrm{S}_{1}$ & 0.37 & 0.7 & 6.08 & 5.5 & 0.94 & 1.3 & 1.92 & 2.6 & 9.31 & 10.1 \\
\hline $\mathrm{S}_{2}$ & 0.28 & 0.5 & 3.99 & 4.0 & 0.67 & 0.9 & 1.36 & 1.3 & 6.30 & 6.6 \\
\hline $\mathrm{S}_{3}$ & 0.20 & 0.4 & 2.67 & 2.6 & 0.48 & 0.6 & 0.98 & 1.0 & 4.33 & 4.5 \\
\hline $\begin{array}{c}\text { LSD } \\
(\mathrm{P} \leq 0.05)\end{array}$ & 0.11 & 0.21 & 1.21 & 0.3 & 0.28 & 0.4 & 0.46 & 0.6 & 2.21 & 1.4 \\
\hline
\end{tabular}

Note: AFS1- G. arborea based Agroforestry system; AFS2- C. pentandra based Agroforestry system, $\mathrm{S}_{1}=4 \times 4 \mathrm{~m}, \quad \mathrm{~S}_{2}=4 \times 6 \mathrm{~m}, \mathrm{~S}_{3}=4 \times 8 \mathrm{~m}$

Table 4. Productivity of soybean and wheat crops under G. arborea and C. pentandra agroforestry system

\begin{tabular}{|c|c|c|c|c|c|c|c|c|}
\hline \multirow{2}{*}{ Spacing (m) } & \multicolumn{2}{|c|}{$\begin{array}{c}\text { Grain yield of soybean } \\
(\mathrm{Mg} \mathrm{ha}-1\end{array}$} & \multicolumn{2}{c|}{$\begin{array}{c}\text { Grain yield of wheat } \\
\left(\mathrm{Mg} \mathrm{ha}^{-1}\right)\end{array}$} & \multicolumn{2}{c|}{$\begin{array}{c}\text { Yield reduction of soybean } \\
(\%)\end{array}$} & \multicolumn{2}{c|}{$\begin{array}{c}\text { Yield reduction of wheat } \\
(\%)\end{array}$} \\
\cline { 2 - 10 } & AFS1 & AFS2 & AFS1 & AFS2 & AFS1 & AFS2 & AFS1 & AFS2 \\
\hline $\mathrm{S}_{1}$ & 0.89 & 0.81 & 2.66 & 2.49 & 34.5 & 43.0 & 13.6 & 17.8 \\
\hline $\mathrm{S}_{2}$ & 1.11 & 0.96 & 2.76 & 2.66 & 25.0 & 26.1 & 10.4 & 12.2 \\
\hline $\mathrm{S}_{3}$ & 1.36 & 1.21 & 2.81 & 2.87 & 8.1 & 8.5 & 8.8 & 5.3 \\
\hline Sole crop & 1.48 & 1.42 & 3.08 & 3.03 & & & & \\
\hline $\begin{array}{c}\text { LSD } \\
(\mathrm{P} \leq 0.05)\end{array}$ & 0.28 & 0.27 & 0.28 & 0.29 & & & & \\
\hline
\end{tabular}

Note: AFS1- G. arborea based Agroforestry system; AFS2- C. pentandra based Agroforestry system, $\mathrm{S}_{1}=4 \times 4 \mathrm{~m}, \mathrm{~S}_{2}=4 \times 6 \mathrm{~m}, \mathrm{~S}_{3}=4 \times 8 \mathrm{~m}$ 


\subsection{Soil Organic $C$ under $G$. arborea and $C$. pentandra Stands in Agroforestry System}

The $\mathrm{C}$ stocks in soil exhibited a significant variation under the stands of $C$. pentandra and $G$. arborea due to differences in bulk densities $\left(1.48-1.56 \mathrm{Mg} \mathrm{m}^{-3}\right)$ and $\mathrm{C}$ concentrations (0.58-0.69\%)(Table 5). The $\mathrm{C}$ stocks decreased with an increase in tree spacing and soil depth. After 5 years, mean soil $\mathrm{C}$ stocks varied from 24.1 to $26.3 \mathrm{Mg} \mathrm{ha}^{-1}$ and from 24.9 to $27 \mathrm{Mg} \mathrm{ha}^{-1}$, respectively under stands of $G$. arborea and $C$. pentandra. The $\mathrm{C}$ stocks in soil increased by $6.8-11.9 \%$ under $G$. arborea stands and 5.5-14.5\% under C. pentandra. $\mathrm{C}$ accretion in soil was slightly higher in $C$. pentandra compared to $G$. arborea stands. C sequestration in soil ranged from 1.3 to $3.4 \mathrm{Mg} \mathrm{Cha}^{-1} \mathrm{yr}^{-1}$ in $C$. pentandra, while it varied from 1.6 to $2.8 \mathrm{Mg} \mathrm{C} \mathrm{ha}^{-1} \mathrm{yr}^{-1}$ in $G$. arborea stands (Table 5).

\subsection{Growth, Biomass and C Storage in Poplar Clones Under Agroforestry}

Poplar clones exhibited significant variation in growth, Leaf Area Index (LAI) and photosynthetically active radiation (PAR) after five years of establishment (Table 6).
The stocking density of clones also varied according to the degree of mortality suffered by each clone. It ranged from 464 to 484 . The mortality was lowest in clone 65/27 and highest in clone G 48. Clones 65/27, G48 and D121 achieved comparatively higher dbh, height and clean bole. LAI was also higher in these clones, whereas it was quite low in clones of S7C1 and G3. In contrary, photosynthetically active radiation (PAR) showed a reverse trend. It was higher under clones S7C1 and G3, while lower under clones 65/27, D121 and G48 (Table 6).

A significant clonal variation in biomass was found among different components (Table 7). In 5 year-old clones, the total biomass varied from 48.5 to $62.2 \mathrm{Mg} \mathrm{ha}^{-1}$. Clone $65 / 27$ achieved highest biomass among the five clones tested, whereas clone $\mathrm{S} 7 \mathrm{C} 1$ attained lowest biomass. Biomass storage in the clones followed the order: 65/27 > D121 > $\mathrm{G} 48>\mathrm{G} 3>\mathrm{S} 7 \mathrm{C} 1$. The contribution of different tree components to total biomass was in the order: stems $>$ roots $>$ branches $>$ foliage. For the total biomass, stem contributed from $60.5 \%$ to $68.9 \%$, branches $12.3 \%$ to $15 \%$, roots $13.8 \%$ to $21 \%$ and foliage $3 \%$ to $7 \%$. The root-shoot ratios ranged from 0.16 to 0.27 . It was lowest in clone $\mathrm{S} 7 \mathrm{C} 1$ and highest in clone G48 (Table 7).

Table 5. C socks in soil under G. arborea and C. pentandra agroforestry system

\begin{tabular}{|c|c|c|c|c|c|c|c|c|}
\hline \multirow{2}{*}{ Spacing (m) } & \multicolumn{2}{|c|}{$\begin{array}{c}\text { Soil depth }(0-20 \mathrm{~cm}) \\
\left(\mathrm{Mg} \mathrm{ha}^{-1}\right)\end{array}$} & \multicolumn{2}{|c|}{$\begin{array}{c}\text { Soil depth }(20-40 \mathrm{~cm}) \\
\left(\mathrm{Mg} \mathrm{ha}^{-1}\right)\end{array}$} & \multicolumn{2}{|c|}{$\begin{array}{c}\text { Mean C storage } \\
\left(\mathrm{Mg} \mathrm{ha}^{-1}\right)\end{array}$} & \multicolumn{2}{|c|}{$\begin{array}{l}\text { C accretion } \\
\left(\mathrm{Mg} \mathrm{ha}^{-1}\right)\end{array}$} \\
\hline & AFS1 & AFS2 & AFS1 & $\mathrm{AFS} 2$ & AFS1 & AFS2 & AFS1 & AFS2 \\
\hline$S_{1}$ & 26.9 & 27.6 & 25.7 & 26.3 & 26.3 & 27.0 & 2.8 & 3.4 \\
\hline $\mathrm{S}_{2}$ & 25.8 & 26.5 & 24.8 & 25.1 & 25.3 & 25.8 & 1.8 & 2.2 \\
\hline $\mathrm{S}_{3}$ & 25.1 & 25.5 & 23.1 & 24.2 & 24.1 & 24.9 & 1.6 & 1.3 \\
\hline $\mathrm{S}_{0}$ & 24.3 & 24.1 & 22.7 & 23.1 & 23.5 & 23.6 & & \\
\hline $\begin{array}{c}\text { LSD } \\
(\mathrm{P} \leq 0.05)\end{array}$ & 0.54 & 0.67 & 0.43 & 0.56 & & & & \\
\hline
\end{tabular}

Note: AFS1- G. arborea based Agroforestry system; AFS2- C. pentandra based Agroforestry system, $\mathrm{S}_{1}=4 \times 4 \mathrm{~m}, \quad \mathrm{~S}_{2}=4 \times 6 \mathrm{~m}, \mathrm{~S}_{3}=4 \times 8 \mathrm{~m}$

Table 6. Growth of Populus deltoides clones under Agroforestry

\begin{tabular}{|c|c|c|c|c|c|c|}
\hline Clone & $\begin{array}{c}\text { Stand Density } \\
\left(\text { trees ha }{ }^{-1}\right)\end{array}$ & $\begin{array}{c}\text { Dbh } \\
(\mathrm{cm})\end{array}$ & Total height $(\mathrm{m})$ & Clean bole $(\mathrm{m})$ & LAI & $\begin{array}{c}\text { PAR } \\
\left(\mu \mathrm{mol} \mathrm{s}^{-1} \mathrm{~m}^{-2}\right)\end{array}$ \\
\hline G3 & 464 & 19.3 & 13.6 & 4 & 3.8 & 1075.25 \\
\hline G48 & 467 & 19.7 & 14.5 & 4.9 & 4.1 & 1021.57 \\
\hline $65 / 27$ & 484 & 21.6 & 14.3 & 4.8 & 4.5 & 967.44 \\
\hline D121 & 471 & 20.1 & 13.0 & 3.6 & 4.2 & 984.57 \\
\hline S7C1 & 474 & 13.3 & 11.16 & 3.4 & 2.9 & 1137.44 \\
\hline $\begin{array}{c}\text { LSD } \\
(\mathrm{P} \leq 0.05)\end{array}$ & 11.2 & 3.57 & 1.85 & 0.1 & 0.5 & 40.8 \\
\hline
\end{tabular}


Table 7. Standing biomass $\left(\mathrm{Mg} \mathrm{ha}^{-1}\right)$ of Populus deltoides clones in agroforestry system

\begin{tabular}{|c|c|c|c|c|c|c|}
\hline Clone & $\begin{array}{c}\text { Leaves \& twigs } \\
\left(\mathrm{Mg} \mathrm{ha}^{-1}\right)\end{array}$ & $\begin{array}{c}\text { Stem } \\
\left(\mathrm{Mg} \mathrm{ha}^{-1}\right)\end{array}$ & $\begin{array}{c}\text { Branches } \\
\left(\mathrm{Mg} \mathrm{ha}^{-1}\right)\end{array}$ & $\begin{array}{c}\text { Coarse roots } \\
\left(\mathrm{Mg} \mathrm{ha}^{-1)}\right.\end{array}$ & $\begin{array}{c}\text { Fine roots } \\
\left(\mathrm{Mg} \mathrm{ha}^{-1}\right)\end{array}$ & $\begin{array}{c}\text { Total Biomass } \\
\left(\mathrm{Mg} \mathrm{ha}^{-1}\right)\end{array}$ \\
\hline $\mathrm{G} 3$ & 3.9 & 34.3 & 8.42 & 7.9 & 1.5 & 56.02 \\
\hline $\mathrm{G} 48$ & 3.6 & 34.9 & 7.10 & 10.9 & 1.2 & 57.70 \\
\hline $65 / 27$ & 3.7 & 38.7 & 8.64 & 11.2 & 0.9 & 62.24 \\
\hline $\mathrm{D} 121$ & 1.8 & 40.4 & 8.43 & 8.9 & 1.1 & 59.50 \\
\hline S7C1 & 2.3 & 33.4 & 6.14 & 5.9 & 0.8 & 48.50 \\
\hline $\begin{array}{c}\text { LSD } \\
(\mathrm{P} \leq 0.05)\end{array}$ & 0.46 & 4.2 & 13.2 & 1.35 & 0.14 & 8.22 \\
\hline
\end{tabular}

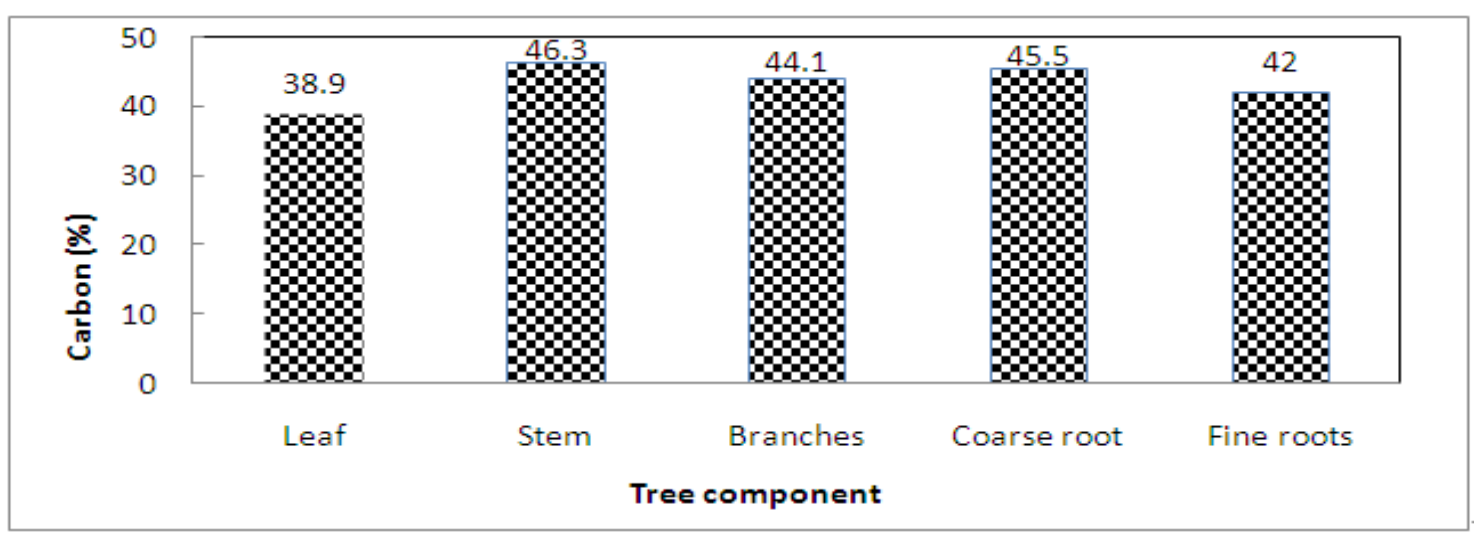

Figure 3. Carbon concentration in different components of $P$. deltoides

Table 8. Carbon stocks in $P$. deltoides clones in agroforestry system

\begin{tabular}{|c|c|c|c|c|c|c|}
\hline Clone & $\begin{array}{c}\text { Foliage } \\
\left(\mathrm{Mg} \mathrm{ha}^{-1}\right)\end{array}$ & $\begin{array}{c}\text { Stem } \\
\left(\mathrm{Mg} \mathrm{ha}^{-1}\right)\end{array}$ & $\begin{array}{c}\text { Branch } \\
\left(\mathrm{Mg} \mathrm{ha}^{-1}\right)\end{array}$ & $\begin{array}{c}\text { Coarse root } \\
\left(\mathrm{Mg} \mathrm{ha}^{-1}\right)\end{array}$ & $\begin{array}{c}\text { Fine root } \\
\left(\mathrm{Mg} \mathrm{ha}^{-1}\right)\end{array}$ & $\begin{array}{c}\text { Total } \\
\left(\mathrm{Mg} \mathrm{h}^{-1}\right)\end{array}$ \\
\hline $\mathrm{G} 3$ & 1.58 & 16.19 & 3.89 & 3.67 & 0.62 & 25.95 \\
\hline $\mathrm{G} 48$ & 1.48 & 16.79 & 3.30 & 5.14 & 0.51 & 27.22 \\
\hline $65 / 27$ & 1.54 & 18.77 & 4.04 & 5.35 & 0.38 & 30.09 \\
\hline $\mathrm{D} 121$ & 0.74 & 19.47 & 3.93 & 4.19 & 0.47 & 28.80 \\
\hline S7C1 & 0.92 & 15.73 & 2.79 & 2.73 & 0.33 & 22.51 \\
\hline $\begin{array}{c}\text { LSD } \\
(\mathrm{P}<0.05)\end{array}$ & 0.21 & 1.7 & 0.76 & 1.3 & 0.12 & 2.72 \\
\hline
\end{tabular}

Carbon concentrations varied within tree components of clones, however no appreciable variation was found among clones for a given component, therefore the average values were taken for accounting $\mathrm{C}$ stocks (Fig. 3). C stocks varied significantly in different components among clones (Table 8). The stems contributed maximum followed by roots and branches, while foliage contributed lowest to total $\mathrm{C}$ storage. The woody components (stems, roots and branches) almost contributed between $94-97 \%$ to total C storage, while foliage from $3 \%$ to $6 \%$. Above ground components contributed from $79.2 \%$ to $86.4 \%$ and below ground components from $14 \%$ to $21 \%$ to total $\mathrm{C}$ stock. Root-shoot $\mathrm{C}$ ratios varied from 0.16 to 0.26 . After 5 years, total $\mathrm{C}$ storage varied from 22.5 to 30.1 $\mathrm{Mg} \mathrm{ha}^{-1}$. Clone 65/27 achieved highest, whereas clone S7C1 minimum $\mathrm{C}$ storage. The $\mathrm{C}$ storage in the clones followed the order: 65/27 > D121 > G48 > G3 > S7C1 (Table 8).

\subsection{Yields of Soybean and Wheat under Poplar Clones in Agroforestry System}

Yields of soybean and wheat crops were significantly reduced under Poplar clones in agroforestry compared to sole crop system (Table 9). Grain yield of soybean varied from 0.99 to $1.29 \mathrm{Mg} \mathrm{ha}^{-1}$ and wheat from 2.67 to $3.01 \mathrm{Mg}$ $\mathrm{ha}^{-1}$ under different clones. Reduction of yield was quite lower $(3.2-10.3 \%)$ in wheat than in soybean, which ranged from $9.2 \%$ to $30.3 \%$. The yield losses of crops were greater under clone 65/27 and lesser under clone S7C1. The yield losses of crops under Poplar clones followed the order: $65 / 27>\mathrm{D} 121>\mathrm{G} 48>\mathrm{G} 3>\mathrm{S} 7 \mathrm{C} 1$. Unlike grain yield, stover 
yields also decreased under clones. The Stover yield of soybean was found to be lowest under clone G3 and highest under clone G3. Similarly, straw yield of wheat was lowest under clone 65/27 and highest under clone G3 (Table 9).

\subsection{Soil Organic C Under Poplar Clones}

Poplar clones significantly affected the soil $\mathrm{C}$ stocks due to differences in bulk densities $\left(1.48-1.58 \mathrm{Mg} \mathrm{m}^{-3}\right)$ and $\mathrm{C}$ concentrations $(0.61-0.73 \%)$ (Table 10). The C stocks decreased with an increase in soil depth. After 5 years, mean soil $\mathrm{C}$ stocks varied from 25.7 to $27.5 \mathrm{Mg} \mathrm{ha}{ }^{-1}$. C sequestration in soil ranged from 2.9 to $4.7 \mathrm{Mg} \mathrm{ha}^{-1} \mathrm{yr}^{-1}$ under different clones in comparison to sole crop system (control)(Table 10).

\subsection{Stocks Under Three Agroforestry Stands}

Comparative account on $\mathrm{C}$ stocks in three agroforestry systems after 5 years of establishment revealed that Poplar based agroforestry system found to be more promising than $G$. arborea and $C$. pentandra systems (Table 11). Poplar based system accumulated almost $2.4-3.2$ times higher $\mathrm{C}$ storage in tree components than G. arborea. Similarly, the soil C stocks also1.4 to 2.3 times higher in Poplar compared to $G$. arborea based agroforestry system. The $\mathrm{C}$ stocks in tree components and soil are more or less similar in G. arborea and $C$. pentandra systems, however it was slightly higher in C. pentandra based system. The total $\mathrm{C}$ stocks (tree+soil) were almost 2 -2.7 times higher in Poplar based agroforestry system compared to $G$. arborea and $C$. pentandra based agroforestry systems (Table 11).

Table 9. Productivity of soybean and wheat crops under P. deltoides clones in agroforestry system

\begin{tabular}{|c|c|c|c|c|c|c|}
\hline Clones & $\begin{array}{c}\text { Grain yield of } \\
\text { soybean } \\
\left(\mathrm{Mg} \mathrm{ha}^{-1}\right)\end{array}$ & $\begin{array}{c}\text { Stover yield of } \\
\text { soybean } \\
\left(\mathrm{Mg} \mathrm{ha}^{-1}\right)\end{array}$ & $\begin{array}{c}\text { Grain yield of } \\
\text { wheat } \\
\left(\mathrm{Mg} \mathrm{ha}^{-1}\right)\end{array}$ & $\begin{array}{c}\text { Straw yield of } \\
\text { wheat } \\
\left(\mathrm{Mg} \mathrm{ha}^{-1}\right)\end{array}$ & $\begin{array}{c}\text { Grain yield reduction } \\
\text { in soybean (\%) }\end{array}$ & $\begin{array}{c}\text { Grain yield reduction } \\
\text { Inwheat (\%) }\end{array}$ \\
\hline $\mathrm{G} 3$ & 1.18 & 2.48 & 2.98 & 4.04 & 16.9 & 4.2 \\
\hline $\mathrm{G} 48$ & 1.21 & 3.62 & 2.87 & 3.36 & 14.8 & 5.5 \\
\hline $65 / 27$ & 0.99 & 3.36 & 2.67 & 2.97 & 30.3 & 10.3 \\
\hline D121 & 1.02 & 3.38 & 2.85 & 3.44 & 28.2 & 8.4 \\
\hline S7C1 & 1.29 & 3.28 & 3.01 & 3.53 & 9.2 & 3.2 \\
\hline Sole crop & 1.42 & 3.80 & 3.11 & 4.24 & & \\
\hline $\begin{array}{c}\text { LSD } \\
(\mathrm{P} \leq 0.05)\end{array}$ & 0.13 & 0.54 & $\mathrm{NS}$ & 5.94 & & \\
\hline
\end{tabular}

Table 10. C stocks in soil under $P$. deltoides based agroforestry system

\begin{tabular}{|c|c|c|c|c|}
\hline \multirow{2}{*}{ Clone } & \multicolumn{2}{|c|}{ C stock in soil depth $\left(\mathrm{Mg} \mathrm{ha}^{-1}\right)$} & Mean C $\left(\mathrm{Mg} \mathrm{ha}^{-1}\right)$ & C accretion \\
\cline { 2 - 5 } & $0-20 \mathrm{~cm}$ & $20-40 \mathrm{~cm}$ & & 3.9 \\
\hline G3 & 27.09 & 26.23 & 26.7 & 3.2 \\
\hline G48 & 26.91 & 25.01 & 26.0 & 4.7 \\
\hline $65 / 27$ & 28.54 & 26.91 & 27.5 & 4.3 \\
\hline D121 & 27.92 & 26.35 & 27.1 & 2.9 \\
\hline S7C1 & 26.27 & 25.17 & 25.7 & 22.8 \\
\hline Control & 23.01 & 22.68 & 1.52 & \\
\hline LSD $(\mathrm{P}<0.05)$ & 1.64 & 1.41 & & \\
\hline
\end{tabular}

Table 11. Comparative account on $\mathrm{C}$ storage $(\mathrm{Mg} / \mathrm{ha})$ in three Agroforestry systems

\begin{tabular}{|c|c|c|c|}
\hline Agroforestry system & $\begin{array}{c}\mathrm{C} \text { stocks in trees } \\
\left(\mathrm{Mg} \mathrm{ha}^{-1}\right)\end{array}$ & $\begin{array}{c}\mathrm{C} \text { stocks in soil } \\
\left(\mathrm{Mg} \mathrm{ha}^{-1}\right)\end{array}$ & $\begin{array}{c}\text { Total C storage } \\
\left(\mathrm{Mg} \mathrm{ha}^{-1}\right)\end{array}$ \\
\hline Gmelina arborea & $4.3-9.3$ & $1.3-3.4$ & $5.6-12.7$ \\
\hline Ceiba pentandra & $4.5-10.1$ & $1.6-2.8$ & $6.1-12.9$ \\
\hline Populus deltoides & $22.5-30.1$ & $2.9-4.7$ & $25.4-34.8$ \\
\hline
\end{tabular}




\section{Discussion}

\subsection{Growth and Biomass in Stands of G. arborea, $C$. pentandra and Clones of $P$. deltoides}

Developing mitigation and adaptation strategies to minimize the negative impacts of climate change on ecosystems have prompted a renewed interest in establishing promising tree based land use systems across India. Agroforestry technologies have tremendous potentials in supplying diverse products as well as sequestering significant amount of $\mathrm{C}$ in degraded agro-ecosystems. Plantation establishment is a critical phase, during which the trees require inputs but do not provide economic outputs. The survival of more than $85 \%$ was achieved in stands of $G$. arborea, $C$. pentandra and $P$. deltoides due to planting of quality stock and adopting appropriate management practices (weeding, pruning, irrigation and fertilization) at different stages of stand development. Growth of $G$. arborea stands is comparatively slower than C. pentandra and clones of $P$. deltoides, which is attributed to difference in the genetic potentials of the species. Both $P$. deltoides and $C$. pentandra are recognized as fast growing exotic species, while $G$. arborea is moderately fast growing indigenous species. The results of this study are in line with findings of Chauhan et al. (2009), where it was clearly demonstrated that the indigenous species of Acacia nilotica and Toona ciliata attained poor growth than fast growing exotic species of $P$. deltoides and Eucalyptus teriticornis. Differential growth trajectories in multipurpose trees do not seem to be extraordinary as many workers reported such variations in the past (Puri et al., 2002; Chauhan et al., 2009; Kumar and Nair, 2011).

High biomass production is an important consideration in all tropical tree planting programmes. This is particularly significant in view of the rising $\mathrm{CO}_{2}$ levels and the growing need to sequester it. Total biomass was almost $2.5 \pm 0.3$ to $3.8 \pm 0.3$ times higher in clones of $P$. deltoides compared to stands of $G$. arborea and $C$. pentandra. The higher biomass was achieved in Poplar clones due to fast growth, while the slow growth leads to lower biomass in stands of $G$. arborea. Comparison of biomass with plantation of similar age indicates that present estimates of biomass are well within the range of biomass values found in Poplar plantations studied elsewhere (Fang et al., 1999; Fang et al., 2007; Raizada and Shrivastava, 1989). Fang et al. (1999) observed 53.5 to $60 \mathrm{Mg} \mathrm{ha}^{-1}$ biomass in 6 yr-old clones of $P$. deltoides planted at density of 500 trees $\mathrm{ha}^{-1}$. Labrecque and Teodorescu (2005) reported 66.4 to $72.2 \mathrm{Mg} \mathrm{ha}^{-1}$ biomass in 4 year-old Poplar clones. In contrary, Lodhiyal and Lodhiyal (1997) reported higher biomass ranging from 60 to $108.9 \mathrm{Mg}$ $\mathrm{ha}^{-1}$ in 3-and 4-year-old plantations in Tarai region of U.P., India. The higher dbh and height accompanied with more planting density $\left(666\right.$ trees $\left.\mathrm{ha}^{-1}\right)$ resulted in higher biomass, whereas low stocking density $\left(<540\right.$ trees $\left.\mathrm{ha}^{-1}\right)$ and poor dbh growth was responsible for lower biomass production in our study. Moreover, Poplar grows profusely in moist and fertile sites of Tarai region of north India, while dry sub-humid and low fertility conditions of the study area resulted in less growth. Although, the growth rate of $C$. pentandra stands was relatively higher as compared to G. arborea, however biomass range is more or less similar. This could be attributed to the higher specific gravity $(0.44 \pm 0.11)$ of wood of $G$. arborea, which was almost two times greater compared to $C$. pentandra $(0.23 \pm 0.06)$. Chauhan et al. (2009) also reported slow growth rates in indigenous species and opined that it could be compensated to some extent by their high specific gravity values in wood but the fast growing species are usually preferred by farmers under agroforestry for immediate economic returns, while slow growing species under afforestation and reforestation programmes. Biomass distribution revealed that more biomass was allocated to stems followed by roots, branches and foliage. This is consistent with earlier studies showing more of biomass allocation by woody components in plantations (Lodhiyal et al.,1995; Puri et al., 2002; Chauhan et al., 2009).

\subsection{C stocks in Stands of G. arborea, C. pentandra and Clones of $P$. deltoides}

Results showed that $\mathrm{C}$ concentration varied within tree components of $P$. deltoides, $G$. arborea and $C$. pentandra stands. It was higher in stems followed by roots, branches whereas it was lowest in leaves. A similar trend in C concentration was observed by Singh and Singh (1991) for dry tropical forests of India. C concentration is generally assumed to be $50 \%$ of the dry biomass (IPCC, 2007), however it is usually less than that and varies among tree components and species (Nair and Nair, 2014). Chauhan et al. (2009) reported $43-47 \%$ of C concentrations in different components of multipurpose trees. Similarly Arrora et al. (2014) also found $39.7 \%$ to $51.1 \% \mathrm{C}$ concentration in different components of $P$. deltoides. The $\mathrm{C}$ concentrations in the present study are slightly lower but comparable to the average value of $45.24 \%$ reported by Chhabra and Dadhwal (2004). A marked variation in $\mathrm{C}$ accumulation (22.5 to 30.1 $\mathrm{Mg} \mathrm{C} \mathrm{ha}{ }^{-1}$ ) was found among popular clones. The estimates of $\mathrm{C}$ stocks in our studies are quite lower than those reported by Arrora et al. (2014) and Rizvi et al. (2011), however the values fall within the range and comparable to those reported by Yadava (2010) and Chauhan et al. (2012). The C stocking largely governed by quality planting material (clones), site conditions, age, stand density and management practices adopted. Clones 65/27 and D121 achieved higher C accumulation due to better adoptability and efficient utilization of resources which might result in higher growth and biomass.

$\mathrm{C}$ accumulation was 2-3 times higher in $P$. deltoides clones than G. arborea and C. pentandra stands. The lesser biomass and $\mathrm{C}$ concentrations resulted lower $\mathrm{C}$ accretion in these species, however the $\mathrm{C}$ stocks are comparable with the estimates made elsewhere (Albrecht and Kandji, 2003; Nair et al., 2010). The $\mathrm{C}$ storage in tree components followed the order stems $>$ roots $>$ branches $>$ leaves. Similar trend in C 
was also observed by earlier workers (Chauhan et al., 2012; Arrora et al., 2014).

\subsection{Productivity of Crops under Stands of G. arborea, $C$. pentandra and Clones of $P$. deltoides}

The results indicated that productivity of soybean and wheat crops decreased under agroforestry system. Yield losses were higher under narrow $(4 \times 4 \mathrm{~m})$ compared to wide tree spacing $(4 \times 8 \mathrm{~m})$ in $G$. arborea and C. pentandra stands. The strong competition between trees and crops for above-ground and below-ground resources in narrow tree spacing might result more yield losses. It has been well documented that higher tree stocking exert more competition and drastically reduced crop yields in agroforestry systems (Rao et al., 1998; Puri and Nair, 2004). Yield losses of soybean and wheat were higher under Poplar clones compared to G. arborea and C. pentandra stands. This might be due to higher competition between Poplar clones and crops sharing of light, moisture and nutrient resources. Poplar clones attained higher leaf area index (LAI) than $G$. arborea stands, which resulted in 6-15\% decrease in PAR levels under Poplar clones. Kocabas et al. (1993) reported that a $20 \%$ reduction in radiation throughout growing season would result $15 \%$ lower yield. The Poplars are fast growing species need huge quantities of nutrients, light and moisture for dry matter production. The tree canopies of Poplar intercept maximum solar radiation and also trees efficiently uptake nutrients due to their well-developed crown and root system compared to crops. It was well demonstrated by Puri et al. (1994) that most of the Poplar clones are shallow rooted and their bulk of fine and coarse roots are distributed 0-20 $\mathrm{cm}$ soil depth, where the crop root lies in the same zone. Therefore, both root and light competition exists in Poplar based agroforestry systems. The competition for light, moisture and nutrients due to lack of niche differentiation in resource sharing could be possible cause for yield reduction. The reduction of yields was more under clones $65 / 27$ and D121 that could be attributed to a strong competition with crops for sharing resources. The results were in line with findings of Puri et al. (2002).

Among two crops, soybean grown in rainy season (June-October) showed highest yield reduction compared to the wheat in winter season (December- April). This is due to the fact that $G$. arborea, C. pentandra and P. deltoides are deciduous trees and shed their entire foliage during winter (November to February), which might transmit an higher amount of light (PAR) to wheat crop. On the other hand, the dense foliage in rainy season seems to restrict the transmission of adequate amount of light and resulted in shading, which might cause yield losses in soybean. Therefore, the study suggests introducing appropriate tree and soil management practices, which could able to recover yield losses in soybean under the agroforestry system. The significance of tree management practices in improving the crop yields in tropical agroforestry systems are well documented (Rao et al., 1998; Puri and Nair, 2004; Chauhan et al., 2012).

\subsection{Soil Carbon Under Stands of G. arborea, $C$. pentandra and Clones of $P$. deltoides}

One of the major issues of keeping the soil resource productive and in place could be accomplished by means of maintaining the levels of soil organic carbon. Agroforestry systems helped in improving the status of organic $\mathrm{C}$ in the soil. As the mean $\mathrm{C}$ content of soil increased by $6.8-11.9 \%$ under $G$. arborea, $5.5-14.5 \%$ under $C$. pentandra and $12.7-20.6 \%$ under Poplar stands. Scientifically acceptable evidence to support the positive influence of trees in enhancing soil organic $\mathrm{C}$ is overwhelming (Chavan et al., 1995; Rao et al., 1998; Soto-Pinto et al., 2010; Gupta et al., 2009; Chauhan et al., 2012; Nair and Nair, 2014). The C accumulation in soils under $G$. arborea stands in our study was quite low compared to Chavan et al. (1995), where $47 \%$ of soil C recorded under 10 year old G. arborea stands grown as monoculture on lateritic soil. However, our estimates are comparable to Datta and Dhiman (2001), which showed an increase of $9 \%$ organic $\mathrm{C}$ and $3 \%$ available $\mathrm{N}$ in soil under 12 year stands of $G$. arborea based agroforestry system. In Poplar based agroforestry system, Chauhan et al. (2011) reported $35.6 \%$ increase in the soil organic $\mathrm{C}$ after 6 years of planting, which was quite higher but our estimates comparable to Gupta et al. (2009). They reported that soil organic $\mathrm{C}$ increased significantly with tree age in the $0-15 \mathrm{~cm}$ soil depth and it was $18.6 \%$ higher under 6 year old plantation than in the soils under 1 year old plantation. It is well established fact that soil factors (type, water content, $\mathrm{pH}$, aeration, micro flora etc.), climatic conditions (temperature, rainfall) and litter fall (quantity) determine to a great extent the soil resources (Kaul et al., 2010). In this context it is envisaged that the increased litter input and addition of root residues seems to have improved $\mathrm{C}$ storage under plantation.

The results of the study indicate marked differences in $\mathrm{C}$ content in soil, which gradually decreased with an increase in soil depth under G. arborea, C. pentandra and P. deltoides stands in agroforestry. A significant increase in $\mathrm{C}$ was observed in the topsoil even after short-duration of 5-year plantation. This is in consistent with the findings of earlier workers (Datta and Dhiman, 2001; Chauhan et al., 2012; Arrora et al., 2014). Poplar trees on an average add $3.5 \mathrm{Mg}$ $\mathrm{ha}^{-1}$ of litter fall every year (Arrora et al., 2014). Power (2004) previously demonstrated that that the most marked differences in soil organic $\mathrm{C}$ in the upper than deeper soil layers in plantations. However, the deeper layer seems to be more stable and respond for long term $\mathrm{C}$ sequestration. The higher amount of leaf litter and root residues in surface soil layer might attribute for higher $\mathrm{C}$ pool. Mean annual increment in soil $\mathrm{C}$ under agroforestry stands ranged from 0.6 to $0.94 \mathrm{MgC} \mathrm{ha}^{-1} \mathrm{yr}^{-1}$, which is comparable with 0.16 to $1.08 \mathrm{Mg} \mathrm{C} \mathrm{ha}^{-1} \mathrm{yr}^{-1}$ as reported by Kaur et al. (2002) and Nair and Nair (2014). 


\subsection{Sequestration in G. arborea, C. pentandra and P. deltoides Based Agroforestry System}

$\mathrm{C}$ sequestration by trees and soils together accounted for 4.5 to $6 \mathrm{Mg} \mathrm{C}^{-1} \mathrm{yr}^{-1}$ under P. deltoides, which is slightly lower than values of 5.8 to $6.5 \mathrm{Mg} \mathrm{C} \mathrm{ha}^{-1}$ as reported by Arrora et al. (2014). The Poplar stands in fertile soils Tarai region of India usually attain profuse growth and development as compared sub-humid conditions of Chhattisgarh. The better growth and development resulted in higher biomass, which contributed for greater $\mathrm{C}$ sequestration in Poplar stands grown in Tarai region. Clonal variation found in the $\mathrm{C}$ sequestration of present study do not seems to be extraordinary, which was resulted as a consequence of differential growth and biomass production. A strong genotype $\mathrm{x}$ environment caused such variation. $\mathrm{C}$ sequestration in $G$. arborea and C. pentandra stands was quite lower (1.2-2.54 $\left.\mathrm{Mg} \mathrm{C} \mathrm{ha}^{-1} \mathrm{yr}^{-1}\right)$ as compared to $P$. deltoides. This is presumably due to low biomass $\mathrm{C}$ and soil $\mathrm{C}$ accretion under these stands. However, the $\mathrm{C}$ sequestration rates in 5 year old stands of $G$. arborea and C. pentandra are within the range and comparable to the rates found in other tropical agroforestry system (Albrecht and Kandji, 2003; Nair and Nair, 2014).

\section{Conclusions}

The present study demonstrated that agroforestry system accumulated significant carbon as living biomass, as well as soil carbon, indicating the potential to offer the additional environmental service of $\mathrm{C}$ sequestration. As per the targets of Greening India Mission under the National Climate Change Action Plan targets, 1.5 million (M) ha of degraded agricultural lands and fallows to be brought under agroforestry; about $0.8 \mathrm{M}$ ha under improved agroforestry practices on existing lands and $0.7 \mathrm{M}$ ha of additional lands under agroforestry (Murthy et al., 2013). The studies give a clear indication that $G$. arborea, C. Pentandra and $P$. deltoides could be potentially exploited under agroforestry in sub-humid tropics of Central India for mitigation of climate change due to their promising growth and higher $\mathrm{C}$ sequestration. Among three species, the $P$. deltoides was found outstanding compared to C. pentandra and G. arborea under agroforestry. Clones 65/27 and D121 were identified as most promising clones of Poplar which could able to sequester $5.8 \pm 0.8 \mathrm{Mg} \mathrm{C}^{-1} \mathrm{yr}^{-1}$. However, further there is need to evaluate these clones in a multi locational trials before advocating them under large scale plantations in agroforestry. In case of G. arborea and C. Pentandra, narrow tree spacing $(4 \times 4 \mathrm{~m})$ is suggested for ensuring higher $\mathrm{C}$ sequestration. Shifting from traditional agriculture to $P$. deltoides, $C$. pentandra and $G$. arborea based agroforestry ensure the farmers gaining additional economic benefits of $\mathrm{C}$ sequestration by $\mathrm{C}$ trading under $\mathrm{CDM}$ projects. However, it depends on willingness of the farmers to adopt these potential tree based land use practice.
Crop yields significantly reduced under agroforestry system, which indicates there was competition between trees and crops for sharing and utilizing resources. Although, the yield losses of soybean and wheat were higher under Poplar clones 65/27 and D121, and also in narrow tree spacing of $G$. arborea and $C$. Pentandra, which could be minimized by introducing appropriate tree management practices (lopping, pruning, hoeing, root trenching) to reduce the competition and improve the complementarity to exploit synergies between tree and crop components. The high tree biomass produced in agroforestry could also compensate to a greater extent for yield losses in long run.

Growth rate differences among exotic and indigenous tree species is widely debated across the world but not yet resolved biological issues related to $\mathrm{C}$ sequestration by trees especially in tropical agroforestry systems. Although, the potential exotics like $P$. deltoides and $C$. pentandra are currently confined to a limited area $(<5 \%)$ in India but it will certainly expand in the future to fulfil the growing demands of wood supplies and enhancing $\mathrm{C}$ pools under global treaties. Despite the fact that world over emphasis is given on adopting fast growing exotic species under agroforestry systems especially for $\mathrm{C}$ sequestration and other economic benefits, the ecological consequences and sustainability shall be carefully examined before introducing them in large scale plantations.

\section{Acknowledgements}

Authors are grateful to ICAR, New Delhi for providing funds under AICRP on Agroforestry. We acknowledge the help and technical support received from AICRP staff and students of Department of Forestry, Indira Gandhi Agricultural University (IGAU), Raipur India. The authors also express sincere thanks to Vice-Chancellors' of Guru Ghasidas Vishwavidyalaya, Bilaspur and IGAU, Raipur, India for their kind cooperation and support.

\section{REFERENCES}

[1] Albrecht, A., Kandji, S.T., 2003. Carbon sequestration in tropical agroforestry systems. Agric. Ecosyst. Environ., 99:15-27.

[2] Arrora, G., Chaturvedi, S., Kaushal, R., Nain, A.S., Tewari, S., 2014. Growth, biomass, carbon stocks, and sequestration in an age series of Populus deltoides plantations in Tarai region of central Himalaya. Turk. J. Agric. For., 38: 550-560.

[3] Chauhan, SK., Gupta, N., Ritu., Yadav, S., Chauhan, R., 2009. Biomass and carbon allocation in different parts of agroforestry trees species. Ind. For., 135:981-983.

[4] Chauhan, SK., Gupta, N., Wallia, R, Yadav, S., Chauhan, R., Mangat, P.S., 2011. Biomass and carbon sequestration potential of Poplar wheat intercropping system in irrigated agro-ecosystem in India. J Agric. Sci. Tech., A1:575-586. 
[5] Chauhan, SK., Sharma, R., Sharma, S.C., Gupta, N., Ritu., 2012. Evaluation of Poplar (Populus deltoides Bartr. Ex Marsh) Boundary plantation based Agri-Silvicultural System for Wheat-Paddy Yield and C storage. Int. J Agric. and For., 2(5): 239-246.

[6] Chavan, K.N., Kenjale, R.Y., Chavan, A.S., 1995. Effect of forest tree species on properties of red lateritic soil. J. Ind. Soc. Soil Sci., 43: 43-46.

[7] Chhabra, A., Dadhwal, V.K., 2004. Assessment of major Carbon pools and fluxes of carbon in Indian forests. Climate change, 64:341-360.

[8] Datta, M., Dhiman, K.R., 2001. Effect of some multipurpose trees on soil properties and crop productivity in Tripura area. J. Ind. Soc. Soil Sci., 49: 511-515.

[9] Fang, S., Xu, X., Lu.S., Tang, L., 1999. Growth dynamics and biomass production in short-rotation Poplar plantations: 6 -year results for three clones at four spacing. Biomass and Bioenergy, 17: 415-425.

[10] Fang, S., Xue, J., Tang, L., 2007. Biomass production and carbon sequestration potential of Poplar plantations with different management patterns. J. Environ. Manage., 85:672-679.

[11] Gupta, N., Kukal, S.S., Bawa, S.S. Dhaliwal, G.S., 2009. Soil organic carbon and aggregation under Poplar based agroforestry system in relation to tree age and soil type. Agroforest. Syst., 76:27-35.

[12] IPCC., 2007. Climate change 2007: Mitigation of Climate Change. Working Group III Contribution to the Intergovernmental Panel on Climate Change, Fourth Assessment Report, Bangkok, Thailand. http://www.ipcc.chi/pocreports/index.html.

[13] IPCC., 2014. Summary for Policy makers: Mitigation pathways and measures in the context of sustainable development. Working Group III Contribution to the Intergovernmental Panel on Climate Change, Fifth Assessment Report, Summary for Policy Makers, http://report.mitigation2014.org/spm/ipcc_wg3 ar5 summar y-for-policymakers_approved.pdf.

[14] Kaul, M., Mohren, G.M., Dadhwal, V.K., 2010.Carbon storage and sequestration potential of selected tree species in India. Mitg. Adapt. Strat. Glob. Changes, 15:489-510.

[15] Kaur, B., Gupta, S.R., Singh, G., 2002. Carbon storage and nitrogen cycling in silvipastural system on a sodic soil in north western India. Agroforest. Syst., 54: 21-29.

[16] Kocabas, Z., Mitchell, R.A.C., Craigon, J., Perry, J.N., 1993. Sensitivity analysis of the ARCWHEAT1 crop model: the effect of changes in radiation and temperature. J. Agric. Sci., 120:149-158

[17] Kumar, B.M., Nair, P.K.R., (Eds). 2011. Carbon Sequestration potential of Agroforestry Systems Opportunities and Challenges. Advances in Agroforestry. Springer Science.

[18] Labrecque, M., Teodorescu, T.I., 2005. Field performance and biomass production of 12 willow and Poplar clones in short-rotation coppice in southern Quebec (Canada). Biomass and Bioenergy, 29(1):1-9.

[19] Lodhiyal, L.S., Lodhiyal, N., 1997. Variation in biomass and net primary productivity in short rotation high density Central Himalayan Poplar plantations. For. Ecol. Manage., 98: 167-179.

[20] Lodhiyal, L.S., Singh, R.P., Singh, S.P., 1995. Structure and function of an age series of Poplar plantations in Central Himalayas: I Dry matter dynamics. Ann. Bot., 76:191-199.

[21] Murthy, I. K., Gupta, M., Tomar, S., Munsi, M., Tiwari, R., Hegde, G.T., Ravindranath, N.H., 2013. Carbon sequestration potential of agroforestry systems in India. J. Earth Sci. Climate Change, 4(1):1-7.

[22] Nair, P.K.R., Nair, V.D., 2014. Solid-fluid-gas: the state of knowledge on carbon sequestration potential of agroforestry systems in Africa. Current Opinion in Environ. Sustain., 6: 22-27.

[23] Nair, P.K.R., Nair, V.D., Kumar, B.M., Showalter, J.M., 2010. Carbon sequestration in agroforestry system. Adv. Agron., 108: 237-307.

[24] Nath, P.K., Behera, B., 2011. A critical review of impact of and adaptation to climate change in developed and developing economies. Environ. Dev. Sustain., 13:141-162.

[25] Power, J.S., 2004. Changes in soil carbon and nitrogen after contrasting land use transitions in north eastern Costarica. Ecosystems, 7:134-146.

[26] Puri, S., Nair, P.K.R., 2004. Agroforestry research for development in India: 25 years of experiences of a national program. Agroforest. Syst., 61-62 (1-3):437-452.

[27] Puri, S., Singh, V.,Bhusan, B., Singh, S., 1994. Biomass production and distribution of roots in three stands of Populus deltoides .For. Ecol. Manage., 65:135-147.

[28] Puri, S., Swamy, S.L., Jaiswal, A.K., 2002. Evaluation of Populus deltoides clones under nursery, field and agrisilviculture system in sub humid tropics of central India. New Forests, 23: 45-61.

[29] Raizada, A., Shrivastava, M.M., 1989. Biomass yield and biomass equations for Populus deltoides Marsh. Ind. J. For., 12: $56-61$.

[30] Rao, M.R., Nair, P.K.R., Ong, C.K., 1998. Biophysical interactions in tropical agroforestry systems. Agroforest. Syst., 38: 3-50.

[31] Rizvi, R.H., Dhyani, S.K., Yadav, R.S., Singh, R., 2011. Biomass production and carbon stock of Poplar agroforestry system in Yamunanagar and Saharanpur districts of north-western India. Curr. Sci., 100:736-742.

[32] Sastri, A.S.R.A.S., 2010. Long range regional climate fluctuations/changes and their impact on agriculture- A case study for Chhattisgarh state in Central India. ISPRS Archives XXXVIII-8/W3 Worksop Proceedings: Impact of Climate Change on Agriculture, 156-160.

[33] Singh, L.J., Singh, J.S., 1991. Storage and flux of nutrients in a dry tropical forest in India. Annals of Botany, 68: 263-273.

[34] Soto-Pinto, L., Anzueto, M., Mendoza, J., Ferrer, G.J., de Jong, B., 2010.Carbon sequestration through agroforestry in indigenous communities of Chipas, Mexico. Agroforest. Syst., 78:39-51.

[35] Steel, R.G.D.,Torrie, J. H., 1980.Principles and Procedures of Statistics. $2^{\text {nd }}$ ed. McGraw Hill, New York. 
[36] Swamy, S.L., Mishra, A., Puri, S.,2003 . Biomass production and root distribution of Gmelina arborea under an agrisilviculture system in sub-humid tropics of Central India. New Forests, 26: 167-186.

[37] Verchot, L.V., Noordwijk, M.V., Kandji, S., Tomich, T., Ong, C., Albrecht, A., Mackensen, J., Bantilan, C., Anupama, K.V.,
Palm, C., 2007. Climate change: linking adaptation and mitigation through agroforestry. Mitg. Adapt. Strat. Glob. Change, 12: 901-918.

[38] Yadava, A.K., 2010. Carbon Sequestration: underexploited environmental benefits of Tarai agroforestry Systems. Report and Opinion, 2(11):35-41 